\title{
Conformación de un mercado regional en el golfo de California en el siglo $\mathrm{XIX}^{*}$
}

\author{
Deni Trejo Barajas \\ UNIVERSIDAd AUTónoma de Baja CALIFornia Sur
}

\begin{abstract}
Al tiempo que se colonizaba la porción sur de la península de Baja California, dos puertos, San José del Cabo y La Paz, emergieron como protagonistas importantes de ese proceso. El papel de sus comerciantes era el de realizar el necesario intercambio que permitiera la reproducción de la incipiente economía minero-agropecuaria local; paralelamente, dichos puertos se integraron a los circuitos comerciales que entonces se establecieron en el golfo californiano, y con ello a un mercado regional en formación en el noroeste de México.
\end{abstract}

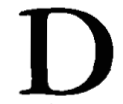

urante la primera mitad del siglo XIX, en el extremo sur de Baja California, la población y sus nuevas formas de asentamiento -pueblos y rancherías- fueron en aumento como resultado de la paulatina disolución del sistema misional y el desarrollo, en contraparte,

* Título original "El papel de los puertos bajacalifornianos en la conformación de un mercado regional en el golfo de California en la primera mitad del siglo xIX", una versión reducida de este trabajo fue presentada como ponencia en el VI Encuentro de Historia Económica del Norte de México en noviembre de 1997. de actividades productivas llevadas a cabo por los particulares, como la minería, la pesca, la agricultura y la ganadería. ${ }^{1}$ El proceso de formación de una

${ }^{1}$ De contar sólo con 4483 individuos en 1835 , el sur de la península había alcanzado en 1857 poco más de 7000 almas. La población estaba distribuida en cuatro municipalidades: tres de ellas, La Paz, San Antonio y Todos Santos -sobre las cuales tenía mayor influencia el puerto de La Paz- alcanzaban casi las 4000 personas, lo que representaba poco más de $50 \%$ de la población del sur peninsular; el resto se concentraba en la jurisdicción municipal de San José del Cabo, que reunía aproximadamente 3334 individuos. Martínez, "Noticias", 1940, p. 29; Lassépas, Historia, 1995, pp. 112-113. 


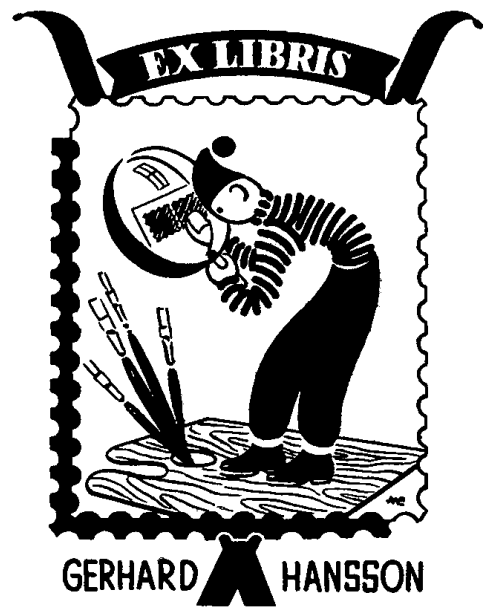

región económica peninsular implicó necesariamente la interacción entre sectores productivos diversos en el interior de la propia región, pero también de ésta con otras zonas que se convirtieron en abastecedoras de productos que no se elaboraban localmente. Era el caso en particular de las harinas y granos de Sonora, indispensables para la alimentación de la población, y de algunos otros productos alimenticios y manufacturas provenientes de otras regiones del macizo continental o del extranjero. Esa dependencia del abastecimiento externo permitió, no obstante, a la par que el fomento de dicha economía local -algunos de cuyos productos, como la plata y las perlas, tenían un alto valor comercial-, su integración a un mercado más amplio que, por esa misma época, se formaba en el noroeste de México y en el cual estaban implicados intereses comerciales extranjeros.

Considero que la formación de una región económica en el sur de Baja California, aunque más tardía con respecto de otras del noroeste mexicano, estuvo en estrecha relación con el proceso de expansión comercial de la zona costera de dicha región noroeste, de ahí que la mayor presencia del comercio marítimo y de los establecimientos portuarios sea uno de los indicadores que nos revelen ciertos rasgos del proceso de integración de un mercado interregional. ${ }^{2}$ No el único, por cierto, dado que existen otros elementos indiscutibles, tales como el aumento de la población, la apropiación privada de los espacios productivos, la formación de una elite de comerciantes, la expansión de un mercado de fuerza de trabajo, una mayor diversificación social y una estructura política consecuente (tendiente por lo general a la centralización). ${ }^{3}$

${ }^{2}$ La actividad comercial en Sonora y Sinaloa empezó a ser muy lucrativa dado que los notables regionales y extranjeros asentados en Mazatlán y Guaymas tenían capacidad económica para importar las mercancías extranjeras y para distribuirlas en los mercados locales a cambio de plata. Para el caso peninsular en nuestra tesis de grado hemos tocado particularmente lat cuestión de la formación de una región económica minero-agropecuaria en el sur de la Baja California y el establecimiento del puerto de Lat Paz. Ortega, Ensayo, 1993, p. 147; Trejo, "Espacio", 1997.

${ }^{3}$ Carol Smith ha planteado que los sistemas de mercado integrados ocurren únicamente en sociedades estratificadas con una clase distinta de productores que no producen alimentos, que están situados en centros urbanos... [dichos] centros y la elite pueden surgir como resultado de fuerzas endógenas o exógenas que 
No abordaremos por ahora todos los factores que hicieron posible la integración de un mercado interregional en el noroeste de México en la primera mitad del siglo XIX. En primer lugar hay que decir que nuestro interés se centra en el estudio de los puertos bajacalifornianos, de ahí que se nos presente con más fuerza el fenómeno de la circulación de mercancías e inevitablemente el de las relaciones de poder entre dichos puertos y los del macizo continental. En apoyo de nuestra perspectiva me parece pertinente mencionar el planteamiento que recoge van Young de que

es en el sistema de intercambio, a través del proceso de distribución, donde aparecen juntas las ofertas de los productores y las demandas de los consumidores. En este sentido, las interconexiones de la red de intercambio son los hilos que mantienen unida a la sociedad. ${ }^{4}$

De hecho la información más rica en lo que toca a intercambio de mercancías, tanto al interior de la península como particularmente entre ésta y el exterior, me ha permitido captar la importancia productiva del extremo sur de Baja California, junto con su respectivo proceso de integración social y económica que se gestó en el transcurso de la primera mitad del siglo XIX.

Me interesó el problema de la circulación, particularmente en lo que toca al noroeste, porque fue notable en la primera mitad del siglo XIX, a la vez

transforman el orden social del lugar, ver Smith, "Sistemas", 1991, p. 88.

${ }^{4}$ Berry, Geography, p. 1, cit. por Young, "Haciendo", 1991, p. 109.

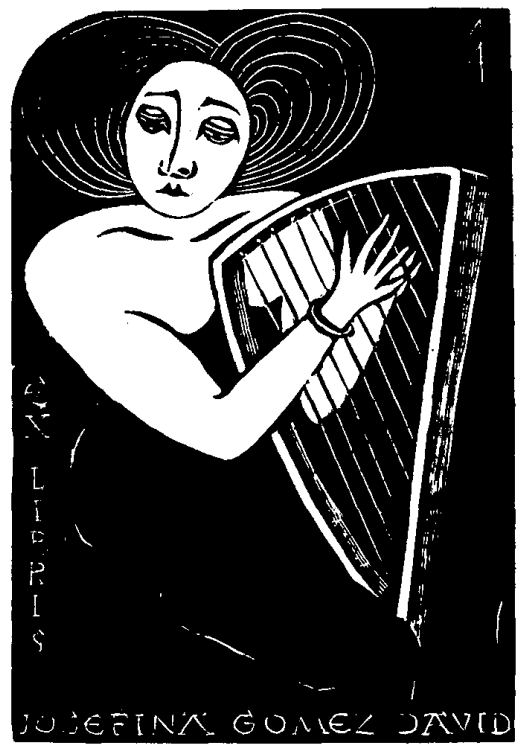

que se integraban social y económicamente algunas zonas, se estructuraba también una red de intercambio comercial en el golfo de California. ${ }^{5}$ Esta red expresaba la interrelación entre productores y consumidores, pero también el importante papel que en este proceso jugaron los distribuidores de mercancías. De hecho, estos últimos fueron determinantes para los productores de las regiones aledañas a los centros de comercialización; por ahora, sin embargo, me interesa desta-

'Sobre las características de las provincias de Sonora y Sinaloa y sus regiones económicas a principios del siglo $\mathrm{xIx}$, véase Voss, Periphery, 1982, pp. 37 y 80-83; Landavazo, Población, 1995, pp. 62-71; Hernández, "Elites", 1995 , pp. 64-69. 
car otra relación, en la cual intervinieron de manera específica los intereses comerciales, porque dio lugar al establecimiento de cierta jerarquía entre los puertos, en este caso entre La Paz y San José del Cabo y entre éstos y los de Mazatlán y Guaymas.

Al comercio marítimo bajacaliforniano dedicaremos particularmente nuestra atención en este trabajo, pues no obstante sus altibajos durante las primeras cinco décadas del siglo XIX, es posible reconocer una tendencia a su aumento y fortalecimiento, lo que evidencia, de manera indirecta, el de la propia actividad productiva local. Asimismo, el estudio de los circuitos comerciales y del contrabando nos permitirá abordar el problema de la articulación de la economía del sur de la península a un mercado más amplio, cuyos principales centros distribuidores se ubicaban en las costas de Sonora y Sinaloa. ${ }^{6}$

Vicisitudes de La PaZ y SaN José DEL CABO COMO PUERTOS DE ALTURA Y DE CABOTAJE

Por los dos principales puertos de la región sur de la Baja California, San

\footnotetext{
${ }^{6}$ Me parece que hay un doble proceso de integración regional: uno el correspondiente a cada una de las subregiones que conforman el noroeste de méxico, y entre las cuales estaría el sur de la península, así como también la región del Pitic en Sonora o la de Culiacán en Sinaloa; y otro, el que se gestó a partir de la interacción de todas esas subregiones en una gran región económica, al modo del "gran norteoriental" del cual habla Mario Cerutti en su estudio Burguesia, 1992, pp. 115-140.
}

José del Cabo y La Paz, se realizó la mayor parte del intercambio comercial de la región. Fue por lo tanto en ellos donde se desarrollaron intereses comerciales que garantizaron la articulación entre las zonas productoras peninsulares y los mercados externos. ${ }^{7}$ A dichos puertos llegaban mercancías de sus respectivas áreas de influencia para ser embarcadas y transportadas a la contracosta de Sonora y Sinaloa o al extranjero, y a ellos llegaban mercancías del exterior que se internaban luego en la península para el consumo de los habitantes o como insumos en sus actividades productivas. Cada uno contaba, sin embargo, con alguna ventaja diferente sobre el otro: en San José del Cabo se conjuntaban la de ser una importante zona de producción agropecuaria y un puerto de arribo de barcos extranjeros procedentes de California, Sudamérica o Islas Sandwich; en La Paz se articulaban la cercanía con el área minera y pecuaria de San Antonio y la condición de capital política y administrativa del territorio peninsular. Aunque La Paz tendió a concentrar la actividad comercial legal de la península, San José del Cabo fue, además de un importante puerto de cabotaje, un lugar propicio para el contrabando. Los dos puertos eran eslabones de un mismo circuito comercial que conectaba a la región sur de la península, por

${ }^{7}$ San José del Cabo era el puerto de la municipalidad más poblada y en donde había la mayor producción agrícola del sur peninsular. La Paz, por su parte, tenía una amplia influencia comercial sobre el resto de la región sureña que comprendía, además de su propia jurisdicción, la de la municipalidad minera y pecuaria de San Antonio y la agrícola de Todos Santos. 
un lado con las casas importadoras de Sonora y Sinaloa, y por otro con el extranjero.

Como veremos en los siguientes párrafos, el funcionamiento de dichos puertos se vio alterado por su apertura o clausura al comercio de cabotaje y de altura, situaciones que tuvieron que ver no sólo con los intereses comerciales en uno y otro puerto, sino con los más poderosos intereses comerciales establecidos en Sonora y Sinaloa. De cualquier forma, aun con esas alteraciones, la actividad comercial llevada a cabo en ellos retroalimentó la incipiente economía peninsular.

Si bien desde finales del siglo XVII el comercio de la península ya se realizaba a través de estos dos puertos, La Paz era en ese entonces apenas un embarcadero en una playa casi desierta. Es hasta la década de 1820 que en su ensenada se empezó a formar un pequeño poblado, con individuos dedicados fundamentalmente a la actividad comercial, en respuesta a las necesidades de intercambio de la zona minera de San Antonio que no contaba con un puerto inmediato. ${ }^{8} \mathrm{~A}$ fines de dicha década el incipiente comercio de La Paz se vio favorecido por ciertas disposiciones, como la habilitación del

\footnotetext{
${ }^{8}$ Se sabe que en 1823 había muy escasos colonos asentados en la bahía de La Paz, por lo que las autoridades promovían su colonización entre los pobladores del sur de la península. Comunicado de José Fernández a José Manuel Ruiz sobre las quejas de los navegantes que llegan al puerto de La Paz y sobre la necesidad de establecer habitantes en dicho lugar, San Antonio, julio 15 de 1823, Archivo Histórico Pablo L. Martínez, de La Paz, BCS (en adelante AHPLM), vol. 15, doc. 177 .
}

puerto para el comercio extranjero en 1828 y el establecimiento de la Subcomisaría de Hacienda y de la Aduana Marítima en 1829. ${ }^{9}$ Con dichas medidas el gobierno intentaba concentrar la actividad comercial en La Paz, a la vez que poner un tope al contrabando, el cual se realizaba por muy diversas playas peninsulares, pero sobre todo por San José del Cabo y San Lucas. El aumento de la población, la concentración de intereses político-administrativos, además de los comerciales, fue un hecho a partir de entonces en La Paz: se sabe que para 1830 las autoridades de gobierno pasaron a residir también en este lugar, abandonando su anterior residencia, que hasta entonces había sido el antiguo presidio de Loreto; para 1835 la población del puerto casi alcanzaba las 800 almas y, según los registros del ayuntamiento, por esos años los comerciantes residentes eran cerca de veinte. ${ }^{10}$

\footnotetext{
9 Respuesta de Ignacio Pérez al subcomisario subalterno de Loreto sobre los puertos habilitados al comercio de altura en la península, Guaynas, octubre 24 de 1828, AHPLM, vol. 21 , doc. 397; Oficio que acompaña el nombramiento de Juan José López como comisario subalterno de La Paz, Alamos, 31 de mayo de 1829, AHPLM, vol. 2, doc. 292; Comunicado sobre el establecimiento de Aduanas marítimas en California, México, 30 de septiembre de 1829, Archivo General de la Nación (en adelante $A G N$ ), Gobernación 6 [sin núm. de exp.].

${ }^{10}$ Según Miguel Martínez, en 1835 había en el puerto de La Paz 785 habitantes. In el segundo lustro de la década de1830 los comerciantes asentados en La Paz eran Manuel Galindo, Cirilo Fierro, Jerónimo Pelato, Francisco Villegas, Manuel Castellanos, José Polo, Eugenio Orozco, Trinidad Meza, Ángel Lebrija, Luis Acosta, Agustín Villegas, Josefa Hipólita, Gabriel Gonzaga, Tomás Fernández, Antonio Ruffo,
} 
El inicial desarrollo del comercio paceño se vio obstaculizado en 1837 al suprimirse el comercio de altura en Baja California. La Paz, San José del Cabo y Loreto fueron declarados a partir de entonces únicamente como puertos de cabotaje, lo que en la práctica eliminó la posibilidad, durante casi dos décadas, de que en la península se realizara un comercio legal directo con los extranjeros, ${ }^{11}$ no obstante los pronunciamientos de algunos vecinos y autoridades respecto a convertir de nueva cuenta a La Paz en puerto abierto al comercio de altura. ${ }^{12}$ El mismo jefe político Rafael Espinosa señalaba en 1849 -y volvería a insistir en el mismo sentido a lo largo de su periodo de gobierno- que no podría

Antonio Belloc, Manuel Amao, Juan Gómez y Francisco de Sosa y Siva, entre otros. Martínez, "Noticias", 1940, p. 19. Lista de tiendas y tendajones que han de pagar los derechos municipales, La Paz, febrero 28 de 1837, AHPLM, vol. 35 bis, doc. 819 .

${ }^{11}$ Oficio de Luis del Castillo Negrete al inspector general de guías y tornaguías, Ignacio Martínez, La Paz, junio 29 de 1837, AHPLM, vol. 35 , doc. 5331.

${ }^{12}$ En 1843 una propuesta consideraba esta alternativa, más la de eliminar San Lucas como receptoría de cabotaje, pero restituyendo dicha oficina en San José del Cabo para apoyar el comercio peninsular, pues se consideraba que así no tendrían que vender los productos locales al precio que imponían los monopolistas de Mazatlán y Guaymas. Se postulaba además, la separación de las Californias (la Alta y la Baja) y la anexión de Baja California a Sinaloa, dado que las relaciones marítimas y comerciales eran mayores con este último lugar y con Sonora que con la Alta California. Propuesta de algunos vecinos de la Baja California para que este territorio forme parte del de Sinaloa, [sin lugar], 1843, AGN, Gobernación 5, exp. 18261845. "fomentarse ni alimentarse la población [...] si no se abría el puerto de La Paz al comercio extranjero". Criticaba a la vez a aquellos que se oponían a esta medida con el pretexto de que con ella se fomentaba el contrabando, pues le parecía que éste existía, "no por la inmoralidad de los empleados sino porque los comerciantes se veían obligados a practicarlo a causa de los altos aranceles". ${ }^{13} \mathrm{El}$ gobernante se refería a los derechos que se pagaban en los puertos que tenían permiso para comerciar con el extranjero -Mazatlán y Guaymas en este caso-, lo que influía en la elevación del precio de las mercancías que llegaban a la península. Tocaba, al jefe político, dos importantes problemas, el de que se permitiera el comercio de altura por La Paz y el de los altos aranceles que pesaban sobre la importación. Ambos tenían que ver con el monopolio comercial ejercido por los importadores de los puertos de Sonora y Sinaloa.

No obstante la insistencia de los comerciantes paceños -y del jefe político- sobre este asunto, no fue sino hasta el año de 1854 cuando por decreto de Antonio López de Santa Anna quedó de nuevo habilitado al comercio extranjero el puerto de La Paz. ${ }^{14}$

${ }^{13}$ Comunicado de Rafael Espinosa al ministro de Relaciones Interiores y Exteriores, Tepic, junio 8 de 1849, AHPLM, vol. 45, doc. 114; Comunicado de la Diputación Territorial remitido por Rafael Espinosa al ministro de Relaciones Interiores y Exteriores, La Paz, lebrero 9 de 1850 , AHPLM, vol. 46, doc. 101.

${ }^{14}$ Decreto sobre la apertura de los puertos de la Baja California, México, enero 12 de 1854, AHPLM, vol. 52, doc. 64. 
Una demanda complementaria surgiría inmediatamente después: la de convertirlo en puerto de depósito, ya que la apertura se había otorgado con la limitación de que las mercancías que se importaran no podrían ser trasladadas a ningún otro puerto de la república; sin embargo, el interés de los comerciantes era no sólo satisfacer el reducido mercado sudpeninsular, sino también llevar mercancías importadas a los más amplios mercados de Sonora y Sinaloa. ${ }^{15}$

La demanda de convertir a La Paz en puerto de depósito resultaba difícil de admitir por las autoridades ya que lesionaba los poderosos intereses comerciales de las casas importadoras de Mazatlán, Guaymas y San Blas, sustentados por una parte en el contrabando (gran parte del cual se hacía en las costas de Baja California), y por otra en la reventa, en las diversas regiones del noroeste -incluida la propia península-, de los productos que aquéllos importaban directamente en sus puertos. ${ }^{16}$ Así que, como era de esperarse, un nuevo decreto en 1856 confirmó que La Paz era puerto habilitado al comercio extranjero para el consumo en el mismo territorio, y en 1857 el ministro de Hacienda reiteraba al jefe político que no se permitiese a los comerciantes peninsulares exportar efectos a Guaymas, Mazatlán, Altata,

${ }^{15}$ Solicitud del ayuntamiento de La Paz al gobierno general de que declare a La Paz como puerto de depósito, La Paz, marzo 13 de 1854 , AHPLM., vol. 53 bis, doc. 449 .

${ }^{16}$ Se sabe que los comerciantes de Mazatlán y Guaymas lograron extender sus intereses a Jalisco, Durango y Chihuahua, Ortega, Ensayo, 1993, p. 147.
San Blas y Manzanillo, ${ }^{17}$ lo que significaba, según creemos, que el comercio de contrabando seguiría dándose por islas y costas deshabitadas, así como por San Lucas, donde tradicionalmente llegaban los barcos balleneros y otros buques mercantes ingleses y estadunidenses. De cualquier forma, la apertura de La Paz al trato directo con los extranjeros a partir de 1854 renovó el comercio peninsular en lo general y el de La Paz en lo particular.

Respecto al puerto de San José del Cabo, de fundación más antigua que La Paz por haber estado asentada en dicho lugar una de las misiones más importantes del extremo sudpeninsular, podemos decir que desde finales del siglo xviI fue un lugar atractivo para el arribo de barcos extranjeros dedicados a la pesca de la ballena, cuyos tripulantes generalmente hacían algunos intercambios con los colonos que vivían en las tierras adyacentes a la misión. La importancia agropecuaria que fue adquiriendo la zona en el transcurso de las primeras décadas del siglo XIX fortaleció dicho comercio y el de cabotaje, gran parte del cual evadía el pago de derechos.

La determinación de las autoridades de concentrar las actividades comerciales de altura en La Paz, a fines de los años veintes, no fue un obstáculo para los moradores de San José del Cabo, quienes continuaron comerciando de manera ilegal con los extran-

\footnotetext{
${ }^{17}$ Decreto de Ignacio Comonfort, México, febrero 8 de 1856, AHPLM, vol. 63 bis, doc. 224; Comunicado de Manuel Siliceo al jefe politico de la Baja California, México, mayo 28 de 1857, AHPLM, vol. 69 [sin núm. de doc.].
} 
jeros. De ello existen algunas pruebas que permiten deducir que el contrabando llegó a tener, por dicho puerto, una no tan despreciable importancia.

Al suprimirse el comercio de altura en 1837, La Paz y San José del Cabo quedaron formalmente en igualdad de circunstancias, sólo como puertos de cabotaje. Sin embargo, comenzó entonces a manifestarse una inquietud entre los pobladores y comerciantes de la zona cabeña respecto a si San José del Cabo o el Cabo de San Lucas, era el que quedaba habilitado al cabotaje en el extremo sur. ${ }^{18}$ Dicha contradicción obedecía al parecer a que corría información en el sentido de que por San Lucas se hacía contrabando, que las autoridades nacionales pretendieron contener al declararlo puerto de cabotaje, pues el encargado respectivo vigilaría y prohibiría los tratos con todos aquellos que desembarcaran mercancías extranjeras; por otro lado, los habitantes de San José reclamaron que esa determinación era absurda, ya que por este último lugar siempre se había realizado el comercio de cabotaje, que de prohibirse causaría grave daño a los intereses de los productores locales. No obstante las manifesta-

\footnotetext{
${ }^{18}$ Mientras que en un oficio del jefe político Castillo Negrete se dice que conforme al nuevo arreglo de puertos quedaban abiertos al comercio de cabotaje La Paz, San José y Loreto, en otro documento que hace referencia al decreto de 17 de febrero de 1837 se especifica que entre los puertos que quedaban abiertos al cabotaje, estaba el de Cabo de San Lucas. Oficio de Luis del Castillo Negrete al inspector de guías y tornaguías, Ignacio Martínez, La Paz, junio 29 de 1837, AHPLM, vol. 35, doc. 5351; Notificación del Ministerio de Hacienda, México, agosto 11 de 1837, AHPLM, vol. 35 bis, doc. 596 .
}

ciones de inconformidad, San Lucas fue designado de manera oficial como puerto de cabotaje. En el transcurso de 1838 se nombró un receptor para dicho lugar, dependiente de la aduana de La Paz, que debía extender su vigilancia hasta San José y costas aledañas para evitar el contrabando. ${ }^{19}$

Esta situación desató una serie de confrontaciones entre los josefinos y las autoridades: en 1843 el jefe político de Baja California envió a las autoridades nacionales una representación de los vecinos del partido de San José en la que éstos pedían que los buques que hacían el comercio de cabotaje pudiesen descargar en la rada de aquel pueblo y no en la de San Lucas; ${ }^{20}$ en respuesta, el comandante general de Sinaloa comunicó al receptor de San José que dicho puerto no se encontraba habilitado para el comercio de cabotaje, y que si habían cargado y descargado buques se debía sólo a la "tolerancia criminal" de las autoridades locales. ${ }^{21}$ Como quiera que sea, el hecho de que San José, y no San Lucas, concentrara buena parte de la población sureña y tuviera en su jurisdicción una importante producción agropecuaria, determinaba el mayor movimiento marítimo comercial de cabotaje, lo que propició que en los hechos la receptoría funcionara en

\footnotetext{
${ }^{19}$ Actas de las juntas en las que se trató el asunto de la aduana de cabotaje en San Lucas, La Paz, marzo 1 de 1838, AHPLM, vol. 36, doc. 367.

${ }^{20}$ Oficio del ministro del Exterior y Gobernación, México, 1843, AGN, Gobernación 271.

${ }^{21}$ Comunicado de la jefatura política al receptor de San José del Cabo, La Paz, 1843 , AHPLM, vol. 41, doc. 188 .
} 
ese lugar. Así lo explicaba el administrador de la aduana marítima de La Paz después de una visita que hizo a la receptoría del Cabo de San Lucas en San José del Cabo a fines de 1849:

Que aunque la ley previene esté situada la Aduana en el Cabo de San Lucas, no se halla ubicada en aquel puerto por falta de población y demás recursos para su establecimiento, por cuyas consideraciones el superior gobierno de este territorio en tiempos del señor don Luis del Castillo Negrete [...] mandó quedase establecida como hasta la fecha se encuentra en esta población de San José, no apareciendo documentación que lo acredite en el archivo respecto a causa de haberse extraviado en la invasión de las fuerzas estadunidenses que hostilizaron con la guerra al país. ${ }^{22}$

Al poco tiempo de esta visita, que corroboró no sólo que el comercio de cabotaje en efecto se hacía por San José, sino también que las propias autoridades locales permitían el contrabando, llegó una orden de cierre de este puerto. Quedó entonces únicamente La Paz habilitada como puerto abierto al comercio marítimo de cabotaje en toda la península, cuestión que puso en un predicamento a los vecinos de San José y de otros puntos cercanos, que entonces se vieron compelidos a llevar por tierra sus productos a La Paz. La inconformidad se manifestó de inmediato entre los jose-

${ }^{22}$ Informe sobre la visita practicada a la receptoría del Cabo de San Lucas en San José por el administrador principal de la aduana marítima del puerto de La Paz, La Paz, enero 29 de 1850, AHPLM, vol. 46 , doc. 61 . finos, quienes en una representación que hicieron llegar al jefe político mencionaban su interés porque se abriera al cabotaje San José del Cabo como antes lo había estado San Lucas. El jefe político manifestó su apoyo a dicha representación, agregando otras razones que, según él, justificaban la medida, tales como la carencia de mulas para transportar las cargas de San José al puerto de La Paz por un camino áspero y montañoso y el contrabando que se hacía por San José del Cabo, que sólo podría ser controlado poniendo allí la receptoría. ${ }^{23}$ Durante 1851 y 1852 creció la inconformidad entre los josefinos por el cierre de su puerto, situación que motivó la sublevación de algunos individuos y la apertura, "de hecho", del puerto de San José del Cabo en $1853 .{ }^{24}$ Las autoridades insistieron un año después en reabrir oficialmente San Lucas, al cabotaje ${ }^{25}$ con lo cual persistieron los problemas por lo menos hasta 1860 en que una disposición del gobierno territorial habilitó ambos puertos para el cabotaje. ${ }^{26}$

${ }^{23}$ Comunicados del jefe político Rafael Espinosa sobre el cierre de los puertos de la Baja California, La Paz, febrero 23 de 1850, AGN, Gobernación 377, exp. 5.

${ }^{24}$ Informe del auxiliar de la aduana de La Paz sobre las consecuencias del cierre del puerto de San José en la Baja California, México, abril 22 de 1853, AGN, Gobernación 425; Comunicado de José María Tornel a Rafael Espinosa en la que dictamina cerrar el puerto de San José a causa de la sublevación de algunos individuos, México, mayo 16 de 1853, AHPLM, vol. 50 , doc. 281 .

${ }^{25}$ Decreto sobre la apertura de los puertos de la Baja California, México, enero 12 de 1854 , AHPLM, vol. 52, doc. 64 .

${ }^{26}$ Las presiones de los josefinos eran tan fuertes y el contrabando tan extendido, que el 
En la controversia que afectaba a San José del Cabo, resalta que sus pobladores no estaban dispuestos a perder la categoría de cabotaje que amparaba a su puerto y que los obligaba a someterse a los intereses de los comerciantes de La Paz (al perder el privilegio del comercio de altura los paceños vieron en los josefinos una competencia desleal). Los vecinos de San José aprovechaban el intercambio directo que hacían de sus productos agropecuarios en Mazatlán o con los buques balleneros para realizar contrabando, por lo que les resultaba arbitrario tener que someterse a los intereses de los comerciantes de La Paz, quienes por su parte tendían a monopolizar el comercio de todo el extremo sur de la península.

Sabemos que hasta 1837 llegaban embarcaciones extranjeras tanto a San José como a La Paz; sin embargo, es evidente que aquél gozó hasta ese momento de mayores ventajas dado

gobierno territorial decidió permitir el comercio con los extranjeros con ciertas restricciones, las que debía vigilar que se cumplieran el administrador de la aduana de San Lucas. Los abusos no se hicieron esperar aprovechando la apertura que otorgaba el gobierno, así que al poco tiempo se volvía a derogar dicha disposición ante la imposibilidad de controlar el contrabando.Circular dirigida al administrador de la aduana de La Paz en el que se le indican las franquicias otorgadas al puerto de San José, La Paz, julio 9 de 1859, AHPLM, vol. 74 bis [sin núm. de doc.]; Oficio dirigido al administrador de la aduana marítima de La Paz sobre los abusos en San Lucas en ocasión de las franquicias otorgadas el 9 de julio, La Paz, noviembre 24 de 1859, ibid.; Decreto de Jerónimo Amador, jefe político del territorio, sobre los puertos habilitados en la Baja California, La Paz, mayo 2 de 1860, AHPLM, vol. 75 [sin núm. de doc.]. que las costas de la zona de Los Cabos eran tradicionales lugares de paso para las naves de otras naciones que iban a los puertos del macizo continental o para los barcos que hacían la pesca de la ballena; además, con el cierre de La Paz al comercio de altura entre los años de 1837 y 1854 , la antigua ventaja de San José y San Lucas con respecto al comercio con los extranjeros volvió a resurgir a causa del cuantioso contrabando que se suponía era realizado en dichos embarcaderos. No obstante esta situación, la concentración de población e intereses comerciales y político-administrativos en La Paz desde 1830, que incluyó el establecimiento de la aduana marítima en este lugar, permitió contrarrestar, hasta cierto punto, las ventajas del puerto josefino, ya que durante ese periodo los comerciantes de La Paz reforzaron su papel de intermediarios de las casas importadoras de Mazatlán y Guaymas. La reapertura de La Paz al comercio extranjero en el año 1854 favoreció al comercio paceño en términos generales, pero sobre todo fortaleció a aquellos comerciantes que en el periodo anterior obtuvieron beneficios del comercio de cabotaje y mostraron habilidad para incursionar en los diversos ámbitos productivos peninsulares, particularmente en la minería y la pesquería de perlas, cuyos productos encontraban mucha aceptación entre los extranjeros. Los comerciantes josefinos, por su parte, lucharían sobre todo por mantener abierto su puerto al cabotaje, pues esta situación les permitía sacar sus productos agropecuarios hacia diversos puntos, así como mantener la comunicación con los 
comerciantes mazatlecos interesados en el contrabando. ${ }^{27}$

No obstante las contrariedades que afectaron el desarrollo de los dos puertos bajacalifornianos, uno puede advertir que aunque los comerciantes de uno y otro lugar parecen mover las mercancías relacionadas con sus respectivas áreas de influencia, persistió una tendencia en la que los comerciantes de La Paz asumieron el papel de intermediarios de todo el comercio peninsular, de ahí su insistencia por extender o mantener sus intereses, no sólo en la zona minera de San Antonio y en la región agropecuaria de Todos Santos, que le quedaban más cercanas, sino incluso en la de San José del Cabo, con la cual había una añeja relación marítimo-comercial, en vista de las dificultades que representaban las comunicaciones terrestres. ${ }^{28}$

${ }^{27}$ En 1850 el administrador de la aduana marítima de Mazatlán decía tener "noticias confidenciales" acerca de una barca estadunidense fondeada en San José del Cabo de San Lucas de la que se pasaron mercancías extranjeras de San Francisco a una embarcación mexicana; también afirmaba saber que un francés llamado Luis Beal, del comercio de Mazatlán y pasajero de uno de los barcos, se había relacionado con los josefinos firmando alianzas comerciales con algunos de ellos. Oficio de Manuel Sánchez Hidalgo al jefe político Rafael Espinosa donde le informa de una nota que le envió el administrador de la aduana marítima de Mazatlán, La Paz, abril 14 de 1850, AHPLM, vol. 46, doc. 217.

${ }^{28}$ El capitán del puerto de La Paz decía en 1836 que en todo el tiempo que había servido en el territorio había sido costumbre que todos los buques de cabotaje, incluso los de La Paz, tocaran en el referido cabo de San José. Oficio de certificación de Juan de Castañeda, capitán del puerto de La Paz, de haber dado permiso al capitán de la goleta Dolores de hacer escala en
En general uno puede advertir que así como el comercio de Mazatlán trató de supeditar a sus intereses a los comerciantes peninsulares al no permitir durante casi dos décadas el restablecimiento del comercio de altura, en el interior de Baja California también los más poderosos intereses mercantiles de La Paz intentaron imponerse a los de San José del Cabo, por medio de su oposición al establecimiento de la aduana de cabotaje en dicho lugar, sobre todo en aquellos periodos en que tuvo prohibido el comercio de altura.

\section{LOS CIRCUITOS MARÍTIMO-COMERCIALES EN EL GOLFO CALIFORNIANO}

La participación en una red de intercambio comercial interregional permitió a los colonos peninsulares vender sus productos mineros, pecuarios y marítimos, a la vez que adquirir los granos, harinas y bienes manufacturados que no se producían internamente; facilitó también la inyección de algunos recursos a las actividades productivas, con lo cual se retroalimentaban la economía y el mismo mercado local.

Habría que decir además que el fortalecimiento de lazos comerciales con sus congéneres del macizo continental y del exterior significó para los peninsulares la integración a un mercado regional en formación en el noroeste -cuyos principales centros distribuidores se localizaban en el golfo de

San José del Cabo, La Paz, enero 2 de 1837, AHPLM, vol. 34, doc. 5. 
California-, el cual implicaba también una interdependencia social y política, con lo que la emergente sociedad del sur peninsular quedó ligada en sus intereses fundamentales a los de las zonas costeras de Sonora y Sinaloa.

Los dos puertos peninsulares a los que nos hemos referido formaban parte del circuito comercial que se fue estableciendo en el golfo californiano desde los últimos años del siglo XviII. En ese sentido hay que recordar que para reforzar el comercio con Californias en la década de 1790 se reconoció a San Blas como puerto de altura, lo que favoreció a su vez al comercio de cabotaje que tenía la tarea de distribuir en los embarcaderos menores los efectos nacionales e importados que llegaban al entonces puerto de Nueva Galicia; a su vez, las pequeñas embarcaciones dejaban en su muelle productos de las localidades bajacalifornianas y norteñas del golfo. ${ }^{29}$

El aumento del tráfico marítimo obligó a que en 1803 los puertos bajacalifornianos fueran reconocidos en la categoría de menores, para que los productos extraídos por ellos no pagaran derechos al llegar a otros embar-

${ }^{29}$ En 1790 , por un tratado de comercio y navegación entre España e Inglaterra, San Blas fue abierto, para casos de extrema necesidad, a embarcaciones inglesas; en 1793, 1794 y 1795 se otorgaron sucesivos permisos y privilegios para el comercio desde España con San Blas y Californias; en 1796 se habilitó el puerto de San Blas para el comercio con puertos de Centro y Sudamérica. Vidargas, "Comercio", 1985, p. 78; Lerdo de Tejada, Comercio, 1967, p. 20; Real orden de 2 de mayo de 1796 , inserta en un bando de 12 de septiembre de 1796, México, Archivo Histórico de Haciẹnda (en adelante AHH), Consulados 217, exp. 7. caderos. ${ }^{30}$ Más adelante, durante la guerra de independencia, los puertos del Pacífico vieron abiertas sus posibilidades de desarrollo con el ímpetu que adquirió el comercio por Panamá. ${ }^{31}$ Bajo el doble efecto de la actividad mercantil generada en el Pacífico y en el golfo de California y de la actitud liberal de las Cortes españolas, éstas decretaron medidas que también favorecieron el tráfico local, como las emitidas en 1814 sobre la exención del diezmo al buceo de perlas en Baja California y la habilitación del puerto de Guaymas, junto con la dispensa de diez años en el pago de impuestos sobre la introducción y extracción de mercancías. ${ }^{32}$

En el transcurso de la década de 1820 será el puerto de Mazatlán el que adquiera mayor importancia en el golfo de California. ${ }^{33}$ Los habitantes del

${ }^{30}$ La real orden fue dada en 22 de octubre de 1803, Vidargas, Navegación, 1982, p. 248.

${ }^{31}$ Gutiérrez, "Comerciantes", 1995, pp. 49. 54; Trejo, "Espacio", 1997, pp. 11-12.

${ }^{32}$ Exposición o memoria sobre el estado natural, civil y político-militar de las provincias de Sonora, Sinaloa y Californias. Dedícalia don Miguel Ramos Arizpe a don J. Canga Argüelles en tiempo de su ministerio (sin lugar y sin fecha), Archivo General de Indias (en adelante AGI), Audiencia de Guadalajara 323-B.

${ }^{33}$ El puerto de Mazatlán fue habilitado para el comercio de altura por un decreto de las Cortes españolas de 9 de noviembre de 1820 junto con San Blas, Acapulco y Tehuantepec. Lerdo de Tejada, Comercio, 1967, p. 21; Inés Herrera señala que San Blas y Mazatlán fueron básicamente abastecedores de las regiones costeras del Pacífico mexicano en la primera mitad del siglo XIX, pero respecto al comercio exterior plantea que fue Mazatlán el puerto más favorecido por la llegada de grupos mercantiles extranjeros, que lo convirtieron en el de mayor movimiento marítimo del litoral oeste, el de- 
sur de la península tendrán con el puerto sinaloense la mayor interacción comercial, en particular desde que les fue negado el tráfico de altura en 1837 y hasta mediados de siglo. Según información recogida por Ulises Urbano Lassépas, entre 1850 y 1857 del total de buques que entraron o salieron de La Paz, la mayor parte procedía de Mazatlán, siguiéndole en orden de importancia, Guaymas, luego Altata y San Blas, y por último otros puertos menores del golfo, así como los extranjeros de San Diego y San Francisco; en el caso de los destinos, igualmente destacaban primero Mazatlán, seguido de Guaymas, luego otros puertos menores del golfo y algunos destinos en el extranjero (en orden de importancia: San Francisco, Sudamérica y Europa).

A partir de estas mismas cifras de movimiento marítimo del puerto de La Paz es posible apreciar también una tendencia a su aumento. Mientras en 1850 llegaron 51 buques, en 1857 se registró la presencia de 118 . De estos últimos, 47 procedían de Mazatlán y 29 de Guaymas. Es interesante hacer notar que los años de mayor movimiento fueron de 1854 a 1857, es decir, desde que el puerto de La Paz fue abierto de nueva cuenta al comercio de altura; sin embargo, el movimiento de buques registrado que se realizaba de manera directa con el extranjero era menor que el que se llevaba a cabo con los puertos nacionales, por lo que puede sugerirse que el creciente flujo de

positario y distribuidor de mercancías que iban de la costa al interior de México, y el centro del comercio costero de San Francisco a Acapulco. Herrera, "Comercio", 1988, p. 131.

CONFORMACIÓN DE UN MERCADO REGIONAL mercancías -incluso las extranjerasde esos años era en su mayor parte resultado del comercio de cabotaje con destinos y procedencias nacionales. ${ }^{34}$ Esto sugiere que durante los años anteriores a la apertura de $\mathrm{La} \mathrm{Paz}$ al comercio extranjero, el comercio de cabotaje se había consolidado como redistribuidor de mercancías tanto nacionales como extranjeras desde Mazatlán y Guaymas, donde estaban asentadas las principales casas comerciales importadoras.

Para los comerciantes de Mazatlán los puertos bajacalifornianos, vistos de manera aislada, no eran con seguridad los más importantes; adquirían relevancia en la medida que formaban parte del circuito comercial por el que transitaban embarcaciones de cabotaje que iban recogiendo y entregando mercancías por los diversos puertos y embarcaderos del golfo californiano. No está de más decir que las ganancias principales quedaban al final en las casas comerciales que se habían establecido principalmente en Mazatlán; para los bajacalifornianos, en cambio, dicho puerto sí era el destino más importante. Según unos Apuntes estadisticos del puerto de Mazatlán del año de 1854, los bultos de mercaderías que salieron de este puerto por medio del comercio de cabotaje se repartían entre Acapulco, Manzanillo, San Blas, Altata, Navachiste, Guaymas, La Paz y San José del Cabo. Por supuesto no es sorprendente que el número de bultos hacia estos dos últimos destinos fueran los menos numerosos, 844 para La Paz y 316 para San José, considerando el

${ }^{34}$ Lassépas, Historia, 1995, pp. 146-147. 
Cuadro 1. Entrada y salida de bultos en el puerto de Mazatlán al fin del año de $\mathbf{1 8 5 4}$

\begin{tabular}{lrr} 
Puertos & Entrada & Salida \\
Acapulco & 1278 & 3066 \\
Manzanillo & 2118 & 7609 \\
San Blas & 12988 & 7204 \\
Altata & 1139 & 2058 \\
Navachiste & 1258 & 4798 \\
Guaymas & 10976 & 3954 \\
La Paz & 3861 & 844 \\
San José del Cabo & 1340 & 316 \\
\multicolumn{1}{r}{ Total } & 34958 & 29849
\end{tabular}

FUENTE: "Apuntes", 1859, pp. 323-337.

pequeño mercado que representaban comparados con los otros puertos; sin embargo, resulta interesante advertir que en las rutas de retorno hacia Mazatlán, los 5201 bultos que entraban procedentes de nuestra región, si bien no eran los más importantes por su número, de cualquier modo eran significativos. Aproximadamente la mitad de los que enviaba Guaymas, el mayor puerto de Sonora.

A partir de algunos registros de entrada y salida de embarcaciones del puerto de La Paz hemos podido conocer las principales rutas que seguían las embarcaciones del comercio de cabotaje del golfo californiano: la primera se circunscribía a los puntos de Mazatlán-La Paz-San José del Cabo, la segunda era más amplia y tocaba los puntos de Mazatlán-San Blas-La PazIsla del Carmen-Guaymas. ${ }^{35}$ General-

${ }^{35}$ Oficios en los que se notifica la salida de la goleta nacional Josefina, La Paz, 1850, AHPLM, vol. 46 , docs. $169,189,287$; Oficios en el que mente los capitanes de los buques no informaban de los embarcaderos intermedios que tocaban; sin embargo, por la noticia de movimiento marítimo de Lassépas, sabemos que no era despreciable el número de embarcaciones procedentes o con destino a puertos menores como Mulegé, Navachiste, Altata o el Río Mayo. ${ }^{36}$

\section{IMPORTACIONES Y EXPORTACIONES:} PRODUCTOS Y PRECIOS

Los cortes de caja de la aduana marítima de La Paz y algunas otras referen.

se notifica la salida de la goleta nacional Carmen Victoria, La Paz, 12 y 23 de abril de 1850, AHPLM, vol. 46 , docs. 208 y 247 ; varios oficios en los que se notifica la entrada y salida de em. barcaciones del puerto de La Paz, La Paz, 1850, AHPLM, vol. 46, docs. 17, 126, 141, 172, 228.

${ }^{36}$ En 1857 el total de barcos procedentes de los puertos menores de Mulegé, Altata $\mathrm{Na}-$ vachiste, Río Mayo y Loreto fue de 26, Lassépas, Historia, 1995, pp. 146-147. 
cias aduanales nos permiten reconocer tres etapas por las que atravesó el comercio de este puerto: en la primera, de 1830 hasta 1837 en que funcionó como puerto de altura, se percibe que el comercio importador adquirió cierta relevancia, lo que sabemos contribuyó al establecimiento de intereses comerciales en dicho lugar; ${ }^{37}$ en la segunda, que va de 1837 a 1854 en que funcionó únicamente como puerto de cabotaje, se aprecia que los ingresos de la aduana descendieron de modo notable $;^{38}$ en la tercera etapa, de 1854 a 1860 en que de nuevo La Paz se abre al comercio extranjero, parece haber un repunte de la actividad económica y de los intereses comerciales, que de inmediato se reflejó en los ingresos aduanales, los que de estar muy disminuidos en la etapa anterior rebasaron los 6000 pesos en un solo semestre de 1854 y los 14000 en $1859 .{ }^{39}$

Es interesante mencionar respecto de la receptoría de San José-San Lucas, sobre la cual contamos con menos información, que la actividad comercial

\begin{abstract}
${ }^{37}$ Durante el periodo de 1830 a 1835 no encontramos cortes de caja aduanales, aunque sí algunas referencias que nos permiten apreciar que los ingresos por derechos de importación llegaron a ser relativamente importantes; por ejemplo, en el año económico de 1831 a 1832 se registra la cantidad de $\mathbf{8} \mathbf{7 7 8}$ pesos por derechos de importación, sin considerar los 30000 pesos que debió pagar el bergantín Gabriela procedente de Filipinas; en 1833 el bergantín Lancaster causó derechos por poco más de 19000 pesos; para el año económico de 1835 a 1836 las entradas de la aduana marítima fueron del orden de los 10322 pesos. Oficio de Juan José López a la Dirección del Ramo de Avío sobre los ingresos, egresos y productos líquidos de caudales que hubo en el año económico que concluyó a fines de junio último, $\mathrm{La} \mathrm{Paz}, 24 \mathrm{de}$ septiembre de 1832, AHPLM, vol. 26, doc. 406; Oficio remitido por la aduana marítima de La Paz al comisario general de Sinaloa respecto a los derechos causados por el bergantín Gabriela, La Paz, 21 de diciembre de 1832, AHPLM, vol. 26, doc. 389; Recibo por 3801 pesos, siete reales, seis granos a cuenta de los derechos del bergantín Lancaster, La Paz, julio 1 de 1833, AGN, Aduanas Marítimas y Fronterizas C-2, exp.1; Memoria, 1837, cuadro núm. 2.

${ }^{38}$ Los ingresos de la aduana marítima, según los datos que tenemos para estos años, no son continuos pero dan una idea de la caída de los ingresos aduanales en este periodo: de fe-
\end{abstract}

brero de 1836 a junio de 1837 los ingresos fueron del orden de los 5084 pesos, pero de julio de 1851 a junio de 1852 fueron de tan sólo 677 pesos, y de julio de 1852 a junio de 1853 de 1164 pesos; según un reporte de 1852 del administrador de la aduana de La Paz, los ingresos por derechos de consumo a los efectos extranjeros nacionalizados que llegaban al territorio eran tan reducidos que no servían ni para cubrir el sueldo del interventor de la federación. Corte de caja de la aduana de La Paz, La Paz, 1837, AHPLM, vol. 35 bis, doc. 830; Corte de caja de la aduana marítima de La Paz del 1 de julio de 1851 al 30 de junio de 1852 , La Paz, junio 30 de 1852, AHPLM, vol. 48, doc. 299; Corte de caja de la aduana marítima de La Paz del 1 de julio de 1852 al 30 de junio de 1853 , La Paz, junio 30 de 1853, AHPLM, vol. 50, doc. 376; Informe del administrador de la aduana de La Paz sobre la administración del $8 \%$ de consumo, según la relación que deben haber rendido los pases en las aduanas marítimas de Mazatlán $y$ Guaymas desde el 10 de febrero hasta diciembre 31 de 1852, [sin lugar], diciembre 31 de 1852, AHPLM, vol. 48 bis, doc. 567.

${ }^{39}$ Cortes de caja de la aduana marítima de La Paz de enero a julio de 1854, La Paz, 1854, AHPLM, vol. 53, doc. 184; vol. 53 bis, docs. 842 y 1017; vol. 54 bis, docs. 1146 y 1306; Cortes de caja mensuales de primera operación de la aduana marítima de La Paz, La Paz, enerodiciembre de 1859 , AHPLM, vol. 74 y 74 bis. 
rendía a la Hacienda pública, a mediados de siglo, alrededor de 1000 pesos anuales. ${ }^{40}$ Aunque en el caso de La Paz los altibajos en los derechos aduanales recolectados sugieren momentos distintos en el desarrollo del comercio, de alguna manera ligados a la apertura o cierre de este puerto al comercio de altura, las exacciones aduanales de San José parecen relativamente estables, aunque expresan el escaso control fiscal que se tenía sobre el comercio de este puerto.

Si bien los ingresos aduanales nos permiten apreciar, a grandes rasgos, las etapas por las que pasó el comercio peninsular, sólo constituyen un indicador muy general, pues como sabemos eran muchas las formas que existían para evadir los impuestos; además, por otra parte, no son una buena fuente para conocer qué productos se comerciaban, ni sus precios, de tal manera que pudiéramos inferir de ello ciertas características de la economía peninsular y sus transformaciones en el curso de la primera mitad del siglo XIX.

${ }^{40}$ En el primer semestre de 1849 los ingresos fueron de 657 pesos y en el segundo semestre de 522; en 1854 fueron del orden de los 900 pesos y de enero a octubre de $1856 \mathrm{de}$ 1000 pesos. Corte de caja de la aduana de San José del Cabo del 1 de enero al 1 de junio de 1849, La Paz, 1849, AHPLM, vol. 45, doc. 103; Noticia pormenorizada de los ingresos y egresos de la receptoría de San José del Cabo de San Lucas de enero a diciembre de 1854, San José del Cabo, 1856, AHPLM, vol. 56 bis, doc. 1207; Noticia de Miguel Canseco sobre la aduana de San Lucas, que remite José María Esteva, visitador general de rentas, concerniente al 1 de enero hasta el fin de octubre de $1856, \mathrm{La}$ Paz, 1856, AHPLM, vol. 65 bis, doc. 1166.
Las limitaciones que encontramos en los cortes de caja aduanales para valorar la importancia del comercio en la economía peninsular se ven relativamente subsanadas con otro tipo de documentos que nos permiten complementar la información que hasta ahora tenemos sobre el estado del intercambio mercantil. Hay que señalar que dicha información no es continua y por lo tanto sigue siendo deficiente nuestro conocimiento sobre dicho proceso. Para el periodo anterior a la reapertura de La Paz al comercio de altura contamos con un documento correspondiente al año de 1849 , la Balanza mercantil de las plazas de La Paz y San José del Cabo de San Lucas, elaborada por el administrador de la aduana marítima de La Paz por orden del gobierno político del territorio a principios de 1850. Por dicho documento sabemos que el valor de los productos locales extraídos de toda la región en aquel año fue del orden de los 19000 pesos y que aproximadamente $60 \%$ de ese valor había salido por La Paz y $40 \%$ por San José del Cabo. En cuanto al valor global de las mercancías introducidas, nacionales y extranjeras, rondaba los 38000 pesos, de los cuales entraron por San José alrededor de $57 \%$ y por $\mathrm{La} \mathrm{Paz,} 43 \%$ (ver cuadro 2).$^{41}$ En el caso de las importa-

41 Una posible explicación de por qué habría una mayor introducción de mercancías extranjeras por San José mientras la extracción de productos locales se hacía por La Paz está en que a aquel puerto seguían llegando embarcaciones extranjeras pese a la prohibición, mientras por La Paz parecía ser más constante el comercio de cabotaje ligado a las actividades mineras. Si revisamos los registros de entradas y 
Cuadro 2. Resumen de la balanza mercantil de las plazas de La Paz y San José del Cabo correspondiente al año de 1849

$\begin{array}{lcccr}\text { Plazas } & \begin{array}{c}\text { Introducción } \\ \text { de efectos } \\ \text { extranjeros }\end{array} & \begin{array}{c}\text { Introducción } \\ \text { efectos } \\ \text { nacionales }\end{array} & \begin{array}{c}\text { Valor total } \\ \text { introducciones }\end{array} & \begin{array}{c}\text { Extracción de } \\ \text { productos } \\ \text { locales }\end{array} \\ & 6403.00 & 10067.25 & 16470.25 & 11450.00 \\ \text { La Paz } & 2094.00 & 19831.00 & 21925.00 & 7517.50 \\ \text { San José del Cabo } & \mathbf{8} 497.00 & 29898.25 & 38395.25 & 18967.50\end{array}$

FUENTE: Balanza comercial de las plazas de La Pazy San José del Cabo de San Lucas, correspondiente al año de 1849, que forma la Aduana Marítima de La Paz, de orden del gobierno politico de este territorio, de fecha 5 de febrero de 1850, Imprenta de Torres, a cargo de luis Vidaurri, México, 1850, BNM, Colección Lafragua 896.

ciones desglosamos los efectos extranjeros de los nacionales, con el objeto de advertir la importancia que tenían estos últimos, cuyo monto era mucho mayor que el de los productos extranjeros, lo que de alguna manera coincidiría con el descenso de los ingresos aduanales peninsulares al disminuir, por consiguiente, el derecho de consumo que se cobraba por las mercancías extranjeras nacionalizadas. Con base en estos datos, uno puede entender también el disgusto de los comerciantes josefinos cuando en el año de 1850 se cerró su puerto al comercio de cabo-

salidas de embarcaciones en San José y La Paz entre 1849 y 1850 , periodo en que ambos puertos se mantuvieron cerrados al comercio de altura, podemos advertir que a San José del Cabo llegaron, además de las consabidas enbarcaciones de cabotaje procedentes de Mazatlán, San Blas y La Paz, varias embarcaciones extranjeras procedentes de Monterrey, California; en La Paz, en cambio, sólo llegaron las embarcaciones del comercio de cabotaje tanto en la ruta hacia San José del Cabo, Mazatián y San Blas, como en la que iba hacia Loreto, Isla del Carmen, Guaymas y Altata. taje, beneficiándose con ello al puerto de La Paz, que quedó por el momento como único lugar para la introducción y extracción de mercancías del territorio bajacaliforniano.

Por desgracia no volvemos a encontrar un informe tan completo como este de 1849, que nos pudiera dar razón del valor de lo comerciado en años posteriores, cuando se volvió a abrir La Paz al comercio de altura; sin embargo, contamos con el cálculo global aproximado que hace Lassépas en 1857 de las importaciones a la península. Menciona, dicho autor, que el valor total de las importaciones anuales se puede considerar en unos 120000 pesos, correspondiendo 70000 a los efectos extranjeros y 50000 a los nacionales, ${ }^{42}$ lo que indicaría que en menos de una década el valor de las importaciones, en su conjunto, se habría triplicado. Además de esta valoración global respecto a la importación, Lassépas nos presenta una lista de las can-

\footnotetext{
${ }^{42}$ Lassépas, Historia, 1995, p. 72.
} 


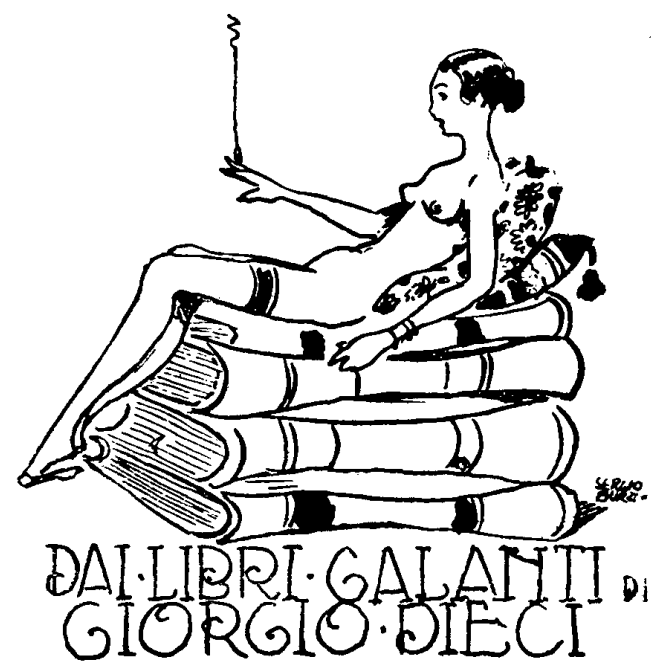

tidades de efectos nacionales y extranjeros importados directamente o nacionalizados para los años de 1854 a 1857. Con sus datos y los de la Balanza comercial de 1849 hemos elaborado un cuadro, con algunos de los productos de consumo más generalizado en la península, que nos permite hacer una comparación entre el volumen comerciado en 1849 con el de 18541857. Las cifras, como se puede apreciar en el cuadro, muestran que las cantidades de mercancías introducidas de 1854 en adelante crecieron de manera notable. El aumento de las importaciones nos estaría indicando dos situaciones no necesariamente contradictorias: que hubo un crecimiento importante del consumo local y que los comerciantes compraron más mercancías para acumular, aprovechando la aper- tura comercial del puerto de La Paz, para luego vender poco a poco en el mercado local o tal vez pensando en la posibilidad de exportar al macizo continental si se les admitía la demanda de convertir a La Paz en puerto de depósito. En relación con la acumulación de mercancías, es posible que se hubiera dado entre 1854 y 1856 , pues ya para el año de 1857 se percibe un descenso en las importaciones que creemos pudo obedecer a una saturación de la oferta de productos importados en la región y a la imposibilidad de reexportarlos a otros puertos de la república como pretendían los comerciantes de La Paz.

Por otra parte hemos hecho algunos cálculos parciales sobre los productos locales extraídos de la península, a partir de la información que ex- 


\section{SECUENCIA}

$\infty$

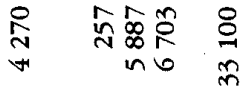

$r$

in

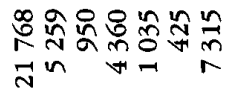

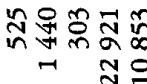

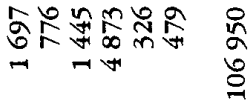

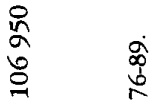

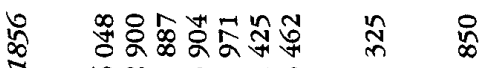

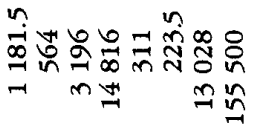
ชำ

그.

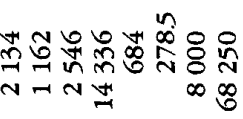

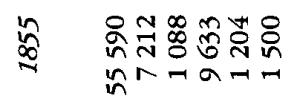

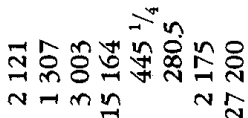

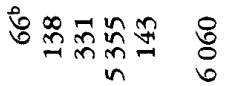

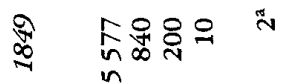

芯
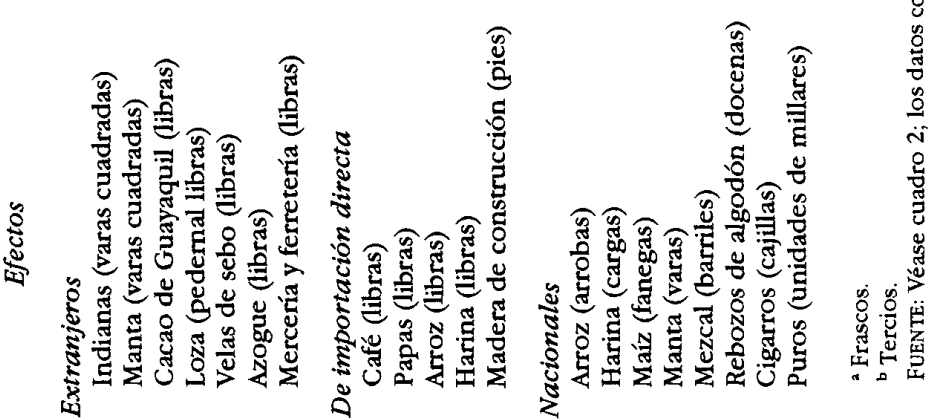
pone Lassépas en su obra. Dicho autor nos muestra las cantidades de mercancías exportadas para los años de 1854 a 1857. Con el objeto de hacer un cálculo aproximado del valor de la exportación de productos locales comparamos también las listas de mercancías extraídas del territorio por el puerto de La Paz en el año de 1849 y 1854. Como la Balanza comercial de 1849 incluye el precio de cada producto, hicimos la prueba de adjudicarle los mismos precios a los productos de la lista de $1854 .{ }^{43}$ El problema fue que un número mayor de mercancías salieron del territorio en el segundo año, por lo que el cálculo resultaba limitado a unos cuantos productos; aun así, contando con los precios de sólo doce productos de 21 que se exportaron en 1854 por La Paz, resultó que el valor total de ellos estaba por encima de los 76000 pesos, muy por encima de los 11450 pesos que era el valor de las mercancías extraídas en 1849 por este mismo puerto, lo que significa que el comercio de exportación de productos locales había aumentado de manera conside. rable. Si a esto agregamos el valor de las exportaciones de minerales, que Antonio del Castillo calculaba entre

\footnotetext{
${ }^{43}$ Hemos comparado los precios de 1849 con otros de 1855 provenientes de una Relación hecha por Miguel Canseco, administrador de la aduana de cabotaje de San José del Cabo, de las salidas de buques habidas en la aduana a su cargo en el año de 1855, San José del Cabo, 1856, AHPLM, vol. 66, doc. 1289 y las diferencias de precios eran mínimas. De entre los productos que pudimos comparar sólo el sebo mostraba un aumento de cuatro reales, el queso, los cueros de res, la carne seca y la panocha se mantuvieron estables.
}

11 o 12000 pesos anuales, es muy probable que el valor total de las exportaciones de productos locales por el puerto de La Paz hacia el segundo lustro de la década de 1850 superara los 90000 pesos al año.

En lo que respecta a las exportaciones de productos locales por San José del Cabo, aunque éstas no eran de la magnitud de las que salían por La Paz a mediados de los años cincuenta, prácticamente se habían duplicado respecto de lo exportado por aquel puerto en 1849. Según hemos visto con anterioridad, por San José habían salido 7517.50 pesos en esquilmos de la ganadería y la agricultura en ese último año de los cuarenta; y según datos de la aduana de cabotaje de San José, para 1855 el valor total de los productos exportados ascendía ya a 13148.68 pesos. ${ }^{44}$

Estos datos nos hacen pensar que, en conjunto, la región sur pudo haber estado exportando (por La Paz y San José), al mediar el siglo, entre 100 y 120000 pesos en productos locales. De hecho un valor similar al de las importaciones. A partir de los datos anteriores podemos hacer un cálculo aproximado sobre la composición de las exportaciones a mediados de siglo: los productos que más impactaban eran la concha y la perla con $60 \%$ del valor total de la exportación; ${ }^{45}$ los de

\footnotetext{
${ }^{44}$ Relación hecha por Miguel Canseco, administrador de la aduana de cabotaje de San José del Cabo, de las salidas de buques habidas en la aduana a su cargo en el año de 1855 , San José del Cabo, 1856, AHPLM, vol. 66, doc. 1289.

${ }^{45}$ Es importante aclarar que el valor de la concha es alto a consecuencia de que ésta se habia acumulado por largo tiempo en las pla-
} 


\section{SECUENCIA}

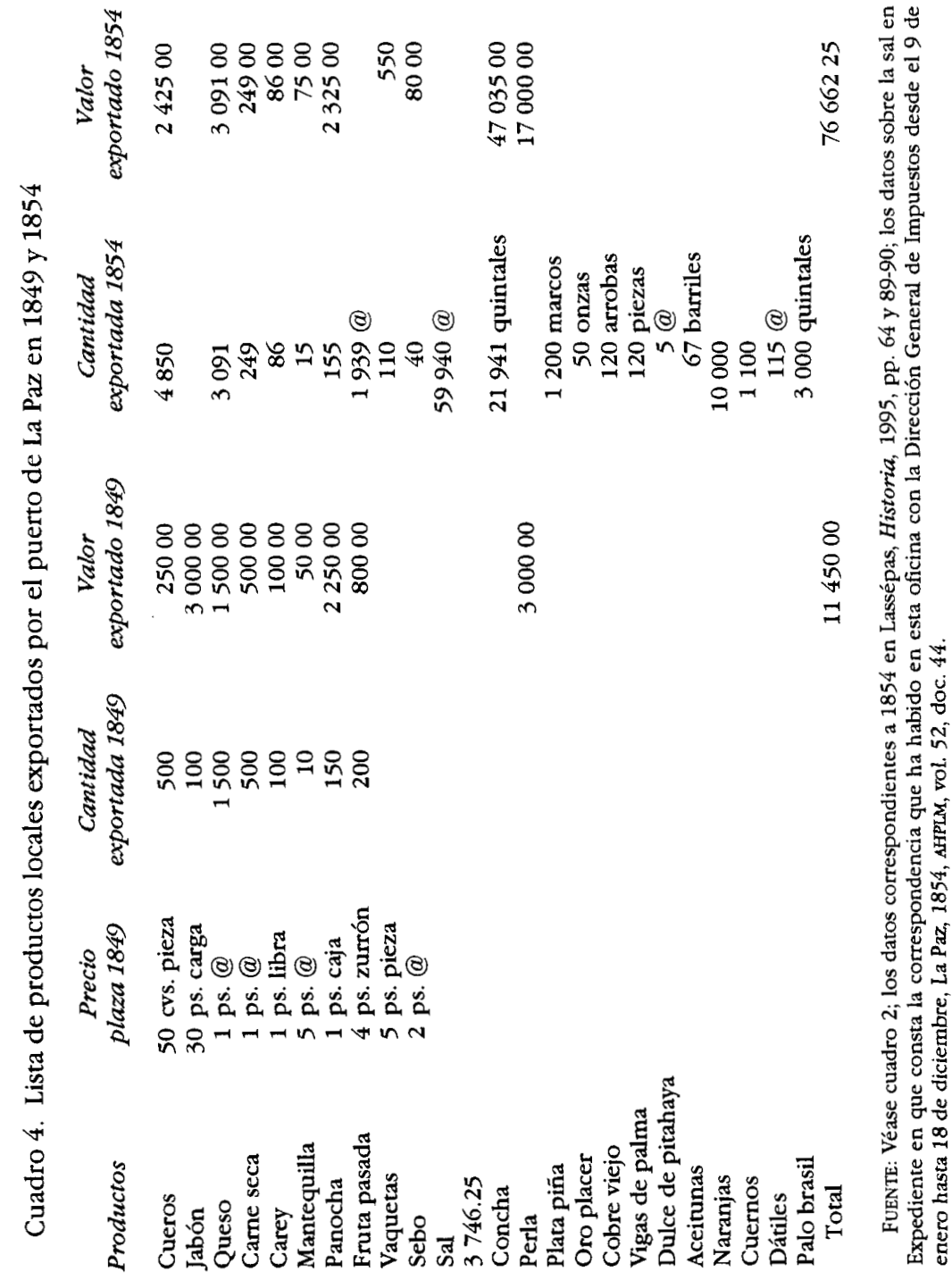


Cuadro 5. Cálculo global del valor en pesos de las exportaciones por los puertos de San José del Cabo y La Paz a mediados de siglo

$\begin{array}{lccr}\text { Productos } & \begin{array}{c}\text { San José } \\ \text { del Cabo }\end{array} & \text { La Paz } & \text { Total } \\ \text { Agrícolas y ganaderos } & 13000 & 10000 & 23000 \\ \text { Minerales } & & 12000 & 12000 \\ \text { Sal } & 3000 & 3000 \\ \text { Perla, concha y carey } & 64000 & 64000 & \\ \quad \text { Total } & 13000 & 99000 & 102000\end{array}$

Fuente: Elaboración de la autora

la ganadería y la agricultura con $20 \%$; los recursos minerales, 15\%; la sal y otros no considerados, $5 \%$. El siguiente cuadro sintetiza los datos sobre las mercancías exportadas y sus valores (con la aclaración de que faltaron varios productos de los cuales no se tuvo noticia de su precio como la fruta pasada, cuernos, palo brasil, entre otros).

De esta revisión de los productos importados y exportados por los puertos peninsulares uno puede concluir que no sólo aumentó, en el transcurso de la década de 1850 , el comercio peninsular, sino que particularmente éste se acentuó por el puerto de La Paz, donde la importación de mercaderías extranjeras, a la vez que la exportación de productos locales de alto valor comercial, como las perlas y la plata, se hizo más notable; mientras que San José del Cabo mantuvo cierto

yas, de ahí que cuando empezó a haber demanda de ella se pudo exportar una gran cantidad en pocos años, pero después disminuyó su volumen y por lo tanto también su impacto en las exportaciones. predominio de las exportaciones agropecuarias. Esto muestra que las zonas productivas peninsulares, pese a sus deficiencias en cuanto a capitalización e incapacidad para atraer suficiente fuerza de trabajo, sobre todo en lo que a la minería se refiere, habían logrado un desarrollo no despreciable, que hizo posible a su vez el fortalecimiento del grupo de comerciantes establecidos en La Paz.

\section{EL CONTRABANDO}

Todos estos datos del comercio de importación y exportación muestran sólo una parte de la actividad comercial peninsular, pues como es bien sabido, el contrabando constituía la otra porción, no menos significativa, del tráfico mercantil en el golfo californiano.

Sabemos que el trato directo con los extranjeros tendió a darse de manera ilegal, principalmente en la zona de Los Cabos, ya que sus costas eran puntos de arribo de las grandes em. barcaciones mercantes y de los buques 
balleneros para conseguir agua, leña y víveres. Desde finales del siglo XVIII las costas peninsulares resultaron fondeaderos obligados para los navegantes extranjeros. En varios incidentes que consignaron las autoridades de la época se hace referencia a embarcaciones que llegaban a alguno de los puertos de la Alta California solicitando ayuda para hacer reparaciones o para conseguir alimentos, agua y leña antes de proseguir su ruta hacia las islas Sandwich o al Asia; estos mismos barcos reaparecían después surcando los mares bajacalifornianos en persecusión de ballenas y nutrias. Se sabe que cada vez que los marinos bajaban a las playas no perdian oportunidad de intercambiar mercaderías por alimentos con los pobladores que encontraban a su paso por las costas peninsulares.

De estos hechos sabemos por varias referencias, entre ellas un informe de 1800 del gobernador interino de Baja California, José Joaquín de Arrillaga, en el que daba cuenta al virrey de Nueva España del nuevo tipo de tráfico marítimo en la zona de su jurisdicción, que según él había aumentado desde la llegada del inglés Locke al cabo de San Lucas en el año de 1794.

El desarrollo del comercio de cabotaje en la segunda y tercera décadas del siglo XIX está ligado también, de alguna manera, al contrabando. Era común que los comerciantes internaran en territorio peninsular mercancía extranjera sin haberla nacionalizado en otro puerto de la república $y$, por lo tanto, sin que hubieran pagado los derechos correspondientes por importación. Si bien dicho comercio era arriesgado, los beneficios podían ser altos dado que se contaba para ese entonces con un mercado cautivo en la península, cuyos pobladores, a la vez que padecían la escasez de varios bienes indispensables, podían pagar con plata pasta de las minas de San Antonio y con productos pecuarios. Es importante insistir en que, en estos años, la plata tuvo que salir necesariamente de contrabando, pues no se explica de otro modo que en las guías de los mercaderes nunca estuviera presente como un producto extraído del territorio.

Por su parte, los comerciantes de las embarcaciones extranjeras no dejaron de interesarse también en el intercambio ilegal, que iba en aumento en la medida en que se acrecentó la población y las producciones sudpeninsulares. Durante los años veinte son constantes las llamadas de atención de las autoridades sobre la existencia del contrabando en la península y sobre la apatía de los responsables locales para combatirlo. En 1828, por ejemplo, Juan Miguel Riesgo, comisario general de occidente, llamaba la atención sobre el "escandaloso tráfico de los buques extranjeros que llegan a esos puertos [de la Baja California]" y hacía una serie de recomendaciones para combatirlo. ${ }^{46}$

Referir algunos de los casos de contrabando de estos años nos puede ayudar a sopesar la importancia que tuvo en el comercio peninsular. En 1824, por ejemplo, la fragata Júpiter, procedente de Manila, comerció mercancías por un valor de 3256 pesos siete reales sin pagar ningún derecho. Años des-

${ }^{46}$ Oficio de Juan Miguel Riesgo, comisario general de occidente, al comisario subalterno 
pués, en 1828 , llegaron por lo menos once barcos extranjeros a los puertos del sur de la península. Seis de ellos evadieron el pago de impuestos (el Diana, Ossean, Banian, Bretaña, Alí y Telémaco); mientras pagaron sólo los bergantines Waberley y Sucre, así como las fragatas Franklin y Correo de Boston. De la fragata francesa Heros, que también arribó en ese año, no tenemos noticia de si pagó o no derechos. Lo curioso es que la Franklin y la Correo de Boston, que sí habían pagado derechos, de cualquier modo hicieron contrabando, pues vendieron mercancía a crédito sobre la cual no pagaron impuestos porque supuesstamente se habían comprometido a cubrirlos los compradores locales. ${ }^{47}$

Un periodo en el que al parecer se acrecentó el comercio de contrabando fue el que se inició después del invierno de 1845-1846, cuando los balleneros intensificaron sus contactos en Baja California para cazar la ballena gris. ${ }^{48}$

de San Antonio, Rosario, Sinaloa, 26 de abril de 1828, AHPLM, vol. 20, doc. 1852.

${ }^{47}$ Documentos sobre el comercio ilegal realizado por la fragata Franklin [varios lugares], 1828-1829, AHPIM, vol. 20, docs. 1763 y 1876; vol. 21 , docs. $320,336,366,486,487$; vol. 22 , doc. 238 ; vol. 23 , docs. $436,451,545,609$; Oficio de Juan Miguel Riesgo al subcomisario de Loreto sobre los negocios que hizo la fragata Correo de Boston, Rosario, Sinaloa, marzo 24 de 1828, AHPLM, vol. 20, doc. 1800.

48 Por una declaración tomada al ciudadano Francisco Betancourt se supo que en los años de 1846,1847 y 1848 concurrieron a la pesca de la ballena en la bahía de la Magdalena 32 fragatas estadunidenses, cuatro francesas y dos holandesas. Expediente que incluye varios documentos en los que se informa sobre la actividad de la caza de ballenas, 1852, AGN, Gobernación 408, exp. 7 .
En esos años, 20 a 25 embarcaciones hicieron la pesca comercial anual de la ballena y de otros animales marinos, mientras los residentes locales los proveían, durante los cuatro meses que duraba la temporada, de carne, queso y productos de las huertas a cambio de manufacturas que los marinos traían consigo ${ }^{49}$ además, precisamente por haber menos control de las autoridades en dicha zona, sus islas y playas despobladas eran lugares propicios para arreglos, no solo entre los comerciantes bajacalifornianos y los extranjeros, sino también entre estos últimos y los importadores de Sonora y Sinaloa. Al respecto, en un comunicado de 1844 se especificaba que, por noticias provenientes de los administradores de las aduanas marítimas del golfo, se sabía que San José y San Lucas eran lugares donde recalaban los buques extranjeros no sólo para contrabandear sino también para recibir las instrucciones de los comerciantes de los puertos de Guaymas, Mazatlán y San Blas..$^{50}$ Para éstos resultaba entonces igualmente provechoso mantener sus ligas con los comerciantes de La Paz y San José, pues de esa manera no sólo dominaban el mercado local peninsular, sino que aseguraban la conexión previa con los importadores extranjeros que llegaban en sus grandes embarcaciones a San José y San Lucas. Así pues, mientras el comercio de La Paz fungía como intermediario legal de

${ }^{49}$ Henderson, "Whalers", 1975, pp. 51-52.

${ }^{50}$ Comunicado de José María Hijar, del gobierno departamental de Sinaloa, al jefe político de la Baja California, Mazatlán, abril 2 de 1844, AHPLM, vol. 42, doc. 69. 


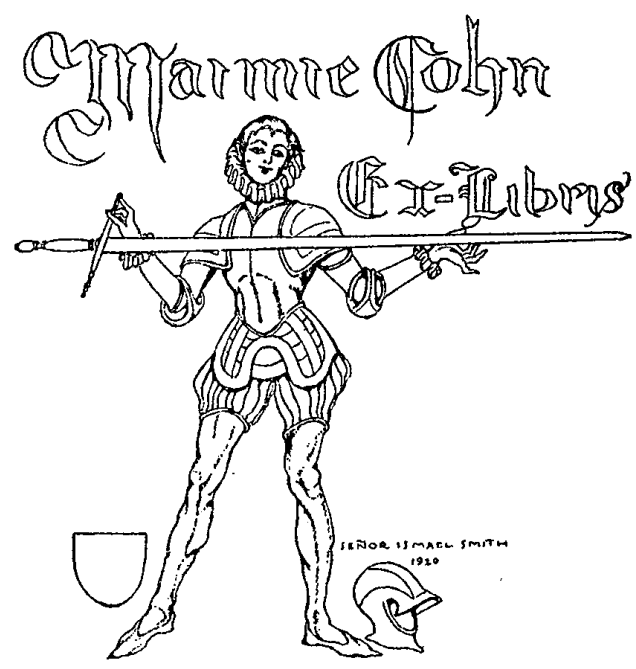

los comerciantes de Sonora y Sinaloa, el de San José del Cabo parecía cumplir el papel de intermediador, pero en el tráfico ilegal y en los arreglos antes de llegar a las aduanas de la contracosta. Notas como la que siguen se encuentran a cada paso en los registros documentales de mediados de siglo:

[Es] notorio el contrabando que se hace en las costas próximas a este puerto [de San Lucas] por los muchos buques extranjeros o nacionales que tocan diariamente a ellas en tránsito a los otros del Pacífico, y aun del abuso que se comete, por los que se les concede cargar y aun descargar efectos en los puntos donde no hay un solo empleado de Hacienda que vigile impidiendo el fraude que pueda cometerse a la sombra de una franquicia que no está autorizada por disposición alguna, sino únicamente por la mal entendida tolerancia de las oficinas de los puertos habilitados que lo han permitido y aún lo permiten algunas veces, con notable perjuicio del erario y comercio de buena fe. ${ }^{51}$

Las reiteradas quejas de algunas autoridades por la existencia del comercio ilegal en las costas del sur de la península, ${ }^{52}$ los conflictos con capitanes de algunas embarcaciones inglesas y estadunidenses acusadas de realizar con-

\$1 Oficio dirigido al administrador de la aduana marítima de La Paz, San Lucas, mayo 15 de 1856, AHPLM, vol. 64, doc. 564 .

32 En una de ellas se pedía al jefe político y al gobierno superior detener los desmanes que hacían los buques extranjeros en las costas peninsulares. Comunicado dirigido al jefe político de La Baja California, La Paz, noviembre 9 de 1857, AHPLM, vol. 70 bis [sin núm. de doc.]. 
trabando en San José del Cabo, ${ }^{53}$ las noticias sobre naves extranjeras que rondaban por las costas e islas peninsulares hasta que había condiciones propicias para descargar, ${ }^{54}$ son algunas de las referencias con las que contamos sobre la existencia del comercio ilegal. Sobre ciertos mecanismos de funcionamiento de este tipo de comercio resulta ilustrativa la descripción que se hizo cuando se formuló, en 1854, la demanda de considerar a La Paz como puerto de depósito. Decía al respecto la representación elaborada por los miembros del ayuntamiento paceño que:

53 Expediente sobre la inconformidad presentada por algunos capitanes de embarcaciones extranjeras por los malos tratos recibidos por las autoridades aduanales en San Lucas, México, 1856, AHPLM, vol. 63 bis, doc. 300.

${ }^{54}$ En 1851 el jefe político Rafael Espinosa informaba que a su llegada a San José del Cabo había observado que continuamente cruzaba las aguas del golfo a la vista de los habitantes una barca inglesa, la cual, según le informó el alcalde, llevaba algunos días haciendo aquella operación; además supo que un pailebot había llevado correspondencia a la barca, después de lo cual había desaparecido. Agregaba que no era fácil saber si había desembarcado clandestinamente algunos efectos pues no había empleado de gobierno. Por su parte, en 1853, el auxiliar de la aduana de La Paz informaba a su superior que en el regreso de su comisión para guardar las costas del cabo de San Lucas, donde había desembarcado mercancía ilegal un buque inglés, se encontró con que había barcos en Surgidero, punta Arena y Los Mártires. Informe de Rafael Espinosa sobre el contrabando en San José del Cabo, La Paz, marzo 31 de 1851, AGN, Gobemación 391, exp. 9; Informe del administrador de la aduana de cabotaje de La Paz sobre el contrabando en San José del Cabo de San Lucas y en las playas adyacentes, que se transmite al ministro de Relaciones Interiores y Exteriores, México, 1853, AGN, Gobernación 425, exp. 2. en la actualidad, cualquier buque deposita sus efectos en la costa o en alguna de nuestras islas adyacentes hasta que con seguridad puedan introducirlos y esto lo hacen sin el menor temor de ser descubiertos. Cuando no [lo] hacen de esa [manera] se ha visto constantemente que los buques que conducen del extranjero algún cargamento de valor están cruzando a la vista de nuestros puertos y muy inmediatos a nuestras costas, dos, tres y [hasta] cuatro meses hasta que descargan clandestinamente o tienen algún arreglo en las mismas aduanas; de manera que sus almacenes de depósito son o nuestras islas y costas o sus propios buques. $i \mathrm{Y}$ habrá comerciante que exponga su cargamento al riesgo, aunque remoto de ser descubierto, por no pagar un derecho insignificante, pudiendo tener sus efectos con toda seguridad?... además esta Aduana [se refiere a la de La Paz] podrá participar a las demás la salida de efectos y sus destinos y éstas tendrán un conocimiento muy útil y del que hoy carecen. ${ }^{55}$

Aunque resulta imposible de cuantificar el valor de este tráfico, la liquidación de los efectos de un bergantín contrabandista atrapado en 1852 en las costas de San José del Cabo, da una idea de lo importante que podía ser este comercio, que al parecer, no era tan ocasional si atendemos a las consabidas quejas de las autoridades. Los efectos del bergantín inglés Portenia fueron valuados en 14456.80 pesos en el momento de su liquidación. Resulta de interés mencionar que, en

"s Solicitud del ayuntamiento de La Paz al gobierno general para que declare a La Paz como puerto de depósito, La Paz, marzo 13 de 1854, AHPLM, vol. 53 bis, doc. 449. 
casos como el del Portenia, el producto del contrabando era distribuido, después de descontar los derechos aduanales que correspondían y los gastos judiciales, entre la aduana marítima de La Paz, el comandante de la aduana, el promotor fiscal y el aprehensor y denunciante, con lo que de cualquier modo quedaban las mercancías dispuestas para su circulación en territorio peninsular. ${ }^{56}$

Entre los años veinte y el medio siglo, época de expansión del comercio inglés y estadunidense en el noroeste de México, el contrabando fue una forma común de introducción y circulación de mercancías extranjeras en la parte sur de la península; pero la introducción no podía ser unilateral, tenía su contraparte en los consumidores potenciales de manufacturas, los cuales tuvieron que desarrollar una capacidad económica suficiente para adquirir los paños, herramientas y demás mercaderías que les llevaban los extranjeros. En el caso de los pobladores peninsulares esta capacidad económica fue el resultado de su dedicación a las actividades minera y pecuaria, cuyos excedentes productivos aprovechó de manera ventajosa el comercio de contrabando.

\footnotetext{
${ }^{56}$ Correspondió a cada parte un noveno, con excepción del aprehensor y denunciante a quien correspondían seis novenos del valor total de la liquidación que incluía el valor de la embarcación. Copia de la liquidación, exacción de derechos y distribución de los efectos aprehendidos en el bergantín inglés Portenia en San José del Cabo de San Lucas, La Paz, junio 30 de 1852, AHPLM, vol. 48, doc. 297.
}

\section{CONCIUSIONES}

En el transcurso de la primera mitad del siglo XIX los puertos bajacalifornianos de San José del Cabo y La Paz se fueron convirtiendo en los principales embarcaderos por los cuales los habitantes del sur peninsular sacaban sus producciones locales (esquilmos de la ganadería y la agricultura, perlas y otros productos del mar, plata pasta y sal, principalmente) e introducían harinas y granos de Sonora, así como textiles y manufacturas que no era posible producir en la localidad. La importancia de las producciones bajacalifornianas, en el comercio que se efectuaba en el golfo, fue creciendo a lo largo del medio siglo, compensando con ello el aumento del consumo de bienes importados.

Tanto el comercio marítimo de cabotaje corno el de altura se desarrollaron en estos años, pero de mancra particular en la década de los cincuenta, al ritmo de la colonización peninsular, de la integración de una economía local, así como del desarrollo comercial de San Blas, Guaymas y Mazatlán, centros mercantiles principales del noroeste de México.

La economía sureña bajacaliforniana se ligó, a través de diversos circuitos mercantiles, al comercio que se efectuó durante esos años en el golfo de California. Dichos circuitos integraban intereses extranjeros y nacionales. En este proceso de formación de lo que podríamos considerar como una red comercial interregional, el puerto de La Paz fue adquiriendo un papel relevante al convertirse en el lugar principal de intermediación mercantil para 
los habitantes peninsulares, tanto en lo que se refiere a sus transacciones internas como en las que tenían que realizar con los comerciantes de Sonora y Sinaloa, que se convirtieron en sus abastecedores. El comercio directo con los extranjeros, que se había perfilado como una de las alternativas para el desarrrollo bajacaliforniano a fines de los años veinte y en el primer lustro de los treinta, fue obstaculizado al prohibirse el comercio de altura en la península a partir del año de 1837 . El resultado de esta medida fue, por un lado, el incremento del contrabando, cuya práctica continuaría de manera intermitente sobre todo por la zona de Los Cabos, y por otro una mayor supeditación de los comerciantes locales a los de la contracosta, lo que facilitó la articulación de la economía local a un mercado más amplio que implicaba a los puertos de Mazatlán, Guaymas y San Blas, los cuales sí gozaban del privilegio del comercio directo con los extranjeros.

Así pues, mientras dichos puertos tendieron a concentrar la mayor parte del comercio importador en el golfo de California, como entradas que eran para los más amplios mercados de sus propias zonas de influencia y del interior del país, a los comerciantes peninsulares no les quedó otra alternativa que convertirse en intermediarios menores de sus colegas importadores de la contracosta continental. Y aquí convendría mencionar que fueron intermediarios en dos sentidos: primero, porque compraban a los comerciantes de los puertos de Mazatlán y Guaymas los bienes importados que luego llevaban a la península para intercambiar por productos locales, y segundo, porque la mercancía obtenida mediante el contrabando que se hacía por San José del Cabo o San Lucas también llegaba a aquellos mismos puertos de Sonora y Sinaloa. Por esas razones, aunque La Paz se perfiló como el puerto reconocido y de mayor importancia comercial y política en la Baja California, San José del Cabo no perdió durante todo este periodo su lugar en los negocios marítimos, pues complementó de modo decidido la actividad mercantil legal con el contrabando. Esta doble relación que se daba en el campo de la distribución de mercancías y que mantuvo ligada a la región sur de la Baja California con la contracosta sonorense-sinaloense, expresaba también, sin lugar a dudas, una interdependencia económica, más allá de la mera distribución, que se tradujo en lazos de unión sociales y políticos entre los pobladores de ambas costas del golfo californiano.

\section{ARCHIVOS}

AGI Archivo General de Indias.

AHH Archivo Histórico de Hacienda.

AHPLM Archivo Histórico Pablo L. Martínez, de la Paz, B.C.S.

AGN Archivo General de la Nación.

\section{Bibliografía}

-"Apuntes estadísticos del puerto de Mazatlán en el año de 1854", Boletín de la Sociedad Mexicana de Geografia y Estadística, 1a. época, t. VII, 1859, pp. 323-337.

-Cerutti, Mario, Burguesía, capitales e industria en el norte de México. Monte- 
rrey y su ámbito regional (1850-1910), Alianza Editorial/Universidad Autónoma de Nuevo León, México, 1992.

-Gutiérrez, Edgar O., "Comerciantes marítimos del noroeste de México. 18101835", Siglo XIX. Cuadernos de Historia, año v, núm. 13, 1995, pp. 49-54.

-Henderson, David A., "Whalers on the coasts of Baja California: opening the peninsula to the outside world", Geoscience and Man, vol. XII, 1975, pp.49-56.

-Hernández Silva, Héctor Cuauhtémoc, "Las elites regionales y la formación del estado de Sonora, 1790-1831", tesis doctoral, COLMEX, México, 1995.

-Herrera Canales, Inés "Comercio y comerciantes de la costa del Pacífico mexicano a mediados del siglo XIX", Revista Historias, núm. 20, 1988, pp.129-135.

-Landavazo Arias, Marco Antonio, "La población urbana en el noroeste de México. Los años formativos (1768-1880)", resis de maestría, Instituto de Investigaciones Dr. José María Luis Mora, México, 1995.

-Lassépas, Ulises U., Historia de la colonización de la Baja California y decreto de 10 de marzo de 1857, UABC, México, 1995.

-Lerdo de Tejada, Miguel, Comercio exterior de México, Banco Nacional de Comercio Exterior, México, 1967.

-Martínez, Miguel, "Noticias estadísticas que para el superior conocimiento del al to gobierno dirige el coronel don Miguel Martínez, relativas al territorio de la Baja California del que es actualmente comandante principal y jefe político superior" en Jorge Flores (comp.), Documentos para la bistoria de la Baja California, Interconti- nental, México, 1940, pp. 3-29 (Papeles Históricos Mexicanos, 2).

-Memoria de la Hacienda Nacional de la República Mexicana, Imprenta del Águila, 1837.

-Ortega Noriega, Sergio, Un ensayo de bistoria regional. El noroeste de México, 1530-1880, UNAM, México, 1993.

-Salmerón, Rubén, La formación regional, el mercado local y el poder de la oligarquia en Sonora: 1740-1840, Universidad de Sonora, México, 1990.

-Smith, Carol A, "Sistemas económicos regionales: modelos geográficos y problemas socioeconómicos combinados" en Pedro Pérez Herrero (comp.), Región e bistoria en México, Instituto Mora/UAM, México, 1991, pp. 37-98.

-Trejo Barajas, Dení, "Espacio y economía en la península de California, 1785 1860", tesis doctoral, Facultad de Filosofia y Letras-UNAM, México, 1997.

-Vidargas, Juan Domingo, "Navegación y comercio en el golfo de California 17401824", tesis de licenciatura, UNAM, México, 1982. el golfo de California" en Memoria de la VII Semana de Información Histórica de Baja California Sur, La Paz, B.C.S., 1985.

-Voss, Stuart F., On the peripbery of nineteenth century Mexico: Sonora and Sinaloa, 1810-1877, The University of Arizona Press, 'Tucson, 1982.

-Young, Eric van, "Haciendo historia regional: consideraciones metodológicas y teóricas" en Pedro Pérez Herrero (comp.), Región e bistoria en México (1700-1850), Instituto Mora/UAM, México, 1991, pp. 99-122. 


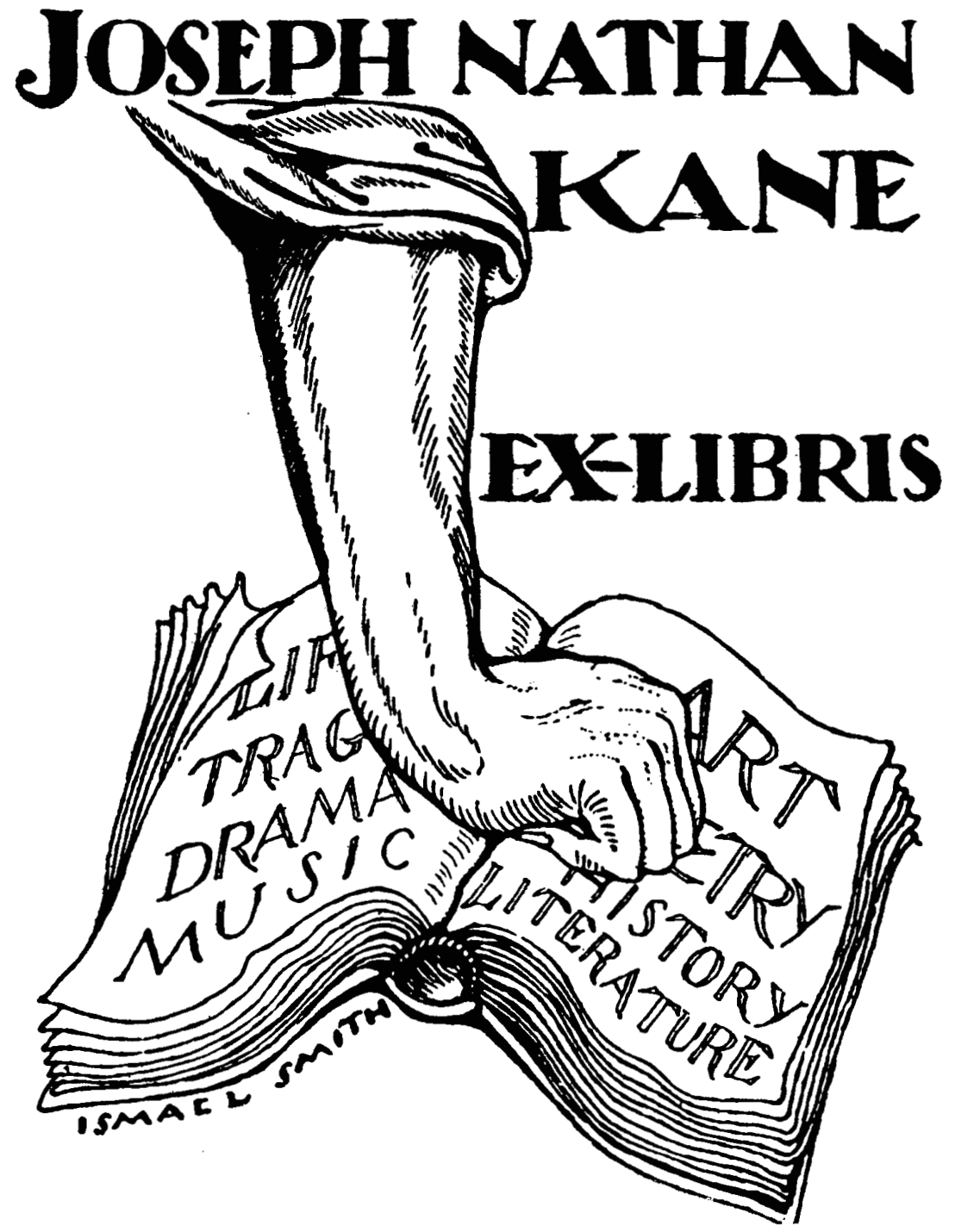

